\title{
How not to talk about passive euthanasia: A lesson from India
}

\author{
IAIN BRASSINGTON
}

\begin{abstract}
The 2011 Shanbaug case has proved to be very important in shaping the debates about end-of-life care and assisted dying in India. Ostensibly dealing with the question of whether it was permissible to withdraw treatment from a patient in a persistent vegetative state, it became a case about the legality of passive euthanasia, which is how it was treated by the Law Commission of India in 2012, and by the Supreme Court bench considering the Common Cause case in 2018. However, questions about the legality of passive euthanasia depend on whether we have a coherent definition of "passive euthanasia". In this paper, I argue that such a definition was absent from both the Shanbaug and the Common Cause rulings. As a result, they are highly unreliable.
\end{abstract}

\section{Introduction}

Much ink has been spilt and many words uttered on the moral questions raised by end-of-life care. The debate has taken place in academic journals and seminar rooms, but also in legislatures and courtrooms around the world. Often, and particularly in respect of euthanasia, these contributions generate more heat than light-and sometimes precious little heat. One reason for this is that there is a degree of unclarity surrounding some of the terms used in the debate. In this essay, I shall examine one such unclarity in respect of the term "passive euthanasia", with a particular focus on how the term has been understood within the Indian legal system. I aim to show that a number of important statements about the legality of passive euthanasia in India are less clear, and therefore potentially less legally robust, than one might hope. This is because - I contend - the people making the

Author: lain Brassington (iain.brassington@manchester.ac.uk), Centre for Social Ethics and Policy/ Law, University of Manchester, Oxford Road, Manchester, M13 9PL, UK.

To cite: Brassington I. How not to talk about passive euthanasia: A lesson from India. Indian J Med Ethics. 2021 Jan-Mar; 6(1) NS: 55-61. DOI:10.20529/ IJME.2020.75.

Published online on July 14, 2020.

Manuscript Editor: Sandhya Srinivasan

Peer Reviewer: Dhvani Mehta

(c) Indian Journal of Medical Ethics 2020 statements have fallen victim to the fallacy of equivocation: they failed to recognise that the term "passive euthanasia" has more than one meaning, and slid between them.

I should say two things at the outset. The first is that I do not intend to contribute to any normative debate about whether and in what circumstances euthanasia should be permitted-I intend only to help clarify the terms at play in any such debate. The second is that the problem I shall illustrate is not confined to the Indian legal system; but it is in India that we find a particularly striking example of it.

In the next section, which presents an abbreviated version of an argument I have made in greater depth elsewhere (1), I shall spend a little time considering the definition of "euthanasia" and how we may categorise euthanasia as active or passive; and I shall look also at a few examples of how the ethical and medico-legal literature has used the term "passive euthanasia". Subsequently, I shall consider how the phrase has been handled in a couple of cases brought before the Supreme Court of India, and how it has been understood by the Law Commission of India. Finally, I shall offer some thoughts on why the definition matters.

\section{Defining euthanasia(s)}

Heather Draper's definition of euthanasia has become something of a touchstone in the literature, and I shall take it as my jumping-off point here. For her, a death by euthanasia

must be defined as death that results from the intention of one person to kill another person, using the most gentle and easy means possible, that is solely motivated by the best interests of the person who dies. (2: $p$ 176)

This definition can probably be simplified a touch. That the death be brought about owing to a motivation to secure the best interests of the one who dies I take to be axiomatic. (Even if one thinks that euthanasia represents a serious wrong, it seems reasonably straightforward to accept that it is markedly different from, say, assassination, and a crucial part of that difference is that assassins do not have any concern for the best interests of their victims.) But since it would always be in the best interests of the one who dies that the means to end his life are the most gentle and easy possible, we can say that intentional killing that does not make use of such means is not 
euthanasia proper: it is, perhaps, attempted euthanasia at best. As such, I shall understand euthanasia to be the intentional ending of one person's life by another, motivated solely by the best interest of the one who dies. Call this 'Definition 1".

We may add to this a distinction between active and passive euthanasia, which terms refer respectively to instances of euthanasia in which a death that is not necessarily otherwise imminent is brought about, and those in which the barriers to an otherwise imminent death are removed. Accordingly, one might offer two further definitions:

Definition 2: Active euthanasia is the intentional ending of one person's life by another, motivated solely by the best interest of the person who dies, through the deliberate administration of a life-ending substance or procedure;

and:

Definition 3: Passive euthanasia is the intentional ending of one person's life by another, motivated solely by the best interest of the person who dies, through the deliberate withholding of a life-preserving substance or procedure.

In a previous edition of this journal, Rohini Shukla has made the interesting suggestion that there might be an important moral distinction between withholding and withdrawing treatment (3); for the sake of this paper, I shall note that point, but put it to one side, and treat "withholding" as covering both situations in which a treatment regime is not begun, and situations in which a treatment regime, once begun, is removed. Accordingly, withdrawing treatment should be thought of as withholding it from this time for ward. The important point at the moment is that the difference between active and passive euthanasia is the difference between intentionally ending a life by doing or administering something that otherwise wouldn't be done or administered, and intentionally ending a life by withholding something that otherwise would or could be administered.

While withholding life-sustaining treatment is a necessary condition of passive euthanasia, it is not, at least under Definition 3, sufficient; the definition does not entitle us to say that every instance of withholding life-sustaining treatment is an instance of passive euthanasia. However, there is a significant number of commentators who do seem to be prepared to make that move, and to endorse the claim that any letting die by withholding treatment is in fact passive euthanasia. This is the position of, for example, Jukka Varelius (4); and on an archived web-page, undated but copyrighted to 2014, the BBC states that

[p]assive euthanasia occurs when the patient dies because the medical professionals either don't do something necessary to keep the patient alive, or when they stop doing something that is keeping the patient alive. (5)

Hence it would appear that there are at least some sources in which the understanding of passive euthanasia can be understood as follows:

Definition 3\#: Passive euthanasia is the ending of one person's life by another, motivated solely by the best interest of the person who dies, through the deliberate withholding of a life-preserving substance or lifepreserving procedure.

The difference between Definition 3 and Definition 3\# lies in the necessity for there to be an intention to end life. Under Definition 3, such an intention is necessary; under Definition $3 \#$, it is not. Correspondingly, more things would properly be called "passive euthanasia" under Definition 3\# than under Definition 3. Therefore, when determining what is and is not an instance of passive euthanasia, we have to pick either Definition 3 or Definition 3\#: we cannot cleave to both. We might expect that any laws or legal opinions that touch on passive euthanasia should pick one and stick to it, too.

It may be tempting to wonder whether we should understand Definition 3 as a subcategory of Definition 3\#.I am resistant to this supposition. It seems important to note that Definition 2 and Definition 3 both add stipulations to Definition 1 about the way in which the intention to end life is realised. In this way, both are, as it were, "narrower". Definition 3\#, by contrast, narrows Definition 1 in one sense, but by removing any intention criterion, it "widens" it in another. As such, going from Definition 1 to Definition 3\# is more radical a move than is going from Definition 1 to Definition 2 or from Definition 1 to Definition 3; and the conceptual map is that bit more complicated. Treating Definition 3 as a subcategory of Definition 3\#, in its turn, would narrow the latter's scope-but only by reintroducing the intention criterion that had been discarded just one conceptual moment before. It all seems rather messy. Neither, really, does it make all that much sense to treat Definition 3\# as a subcategory of Definition 3, since doing so would mean treating it as the kind of intentional ending of life in which the presence or absence of intention does not much matter, and I take this to be oxymoronic.

The upshot of this is that one should choose either Definition 3 or Definition 3\#. For the record, I think that Definition 3 is preferable, and I spell out my reasoning elsewhere (1). But the argument that I shall propose over the coming pages does not depend on which definition for passive euthanasia we choose. All that matters is that that there are competing definitions, and that the law should choose one and apply it consistently. It might be that within a given legal system, Definition 3 or Definition 3\# of passive euthanasia is the one that holds. What matters for my current purposes is that it is important that one, and just one, does hold, so that people who are governed by the law stand a chance of knowing what it is.

\section{Passive euthanasia in Indian law: The Shanbaug case}

The development of the law surrounding passive euthanasia in India provides an interesting example of how these definitions play out in the "real world".The matter crystallised in 
2011 in the Shanbaug case, heard in the Supreme Court by Justices Markandey Katju and Gyan Sudha Misra (6). This case concerned a woman, Aruna Ramachandra Shanbaug, who, after a particularly brutal sexual assault, had been left in a persistent vegetative state for almost 40 years. (Establishing her precise diagnosis occupied paragraphs 7-9 of the judgment, which was delivered by Justice Katju.) The question before the Supreme Court concerned whether leave should be given to halt artificial nutrition; whether this would be permissible under the terms of the Indian Constitution's Article 21 guarantee of a right to life was not clear.

In the 1996 Gian Kaur case, Justice Jagdish Sharan Verma had stated that "that right to live of which Article 21 of the Constitution speaks of [sic] can be said to bring in its trail the right not to live a forced life". (7) Accordingly, if the right to life does not require that one remain alive, it should be seen as waivable; and as such, one would be entitled to refuse lifesustaining treatment.

However, the Shanbaug case was brought not by Ms Shanbaug herself-she had not expressed, nor could she express, any wish to die or to have treatment removed-but by the writer Pinki Virani (6: para 2). As such, it was less about a person's ability to waive their own rights than it was about what duties others have in respect of those rights. Granted that Ms Shanbaug had a constitutional right to life, ought that to be taken to mean that others simply had a duty not to kill her, or to mean that they had a duty to apply and maintain procedures to preserve her life? If the latter, what would these procedures be? What would it be reasonable to expect people to do in the discharge of that duty, granted that it may not be reasonable to expect medical staff to do everything conceivably possible? If there is no reasonable hope that a patient will recover, is there still a duty to treat? What if the patient's general well-being is deteriorating?

In approaching these questions, Katju J referred at length to overseas cases, not the least of which was the English case of Bland (8). Heard in 1993, this case concerned the withdrawal of nutrition and hydration from a man who had been in a persistent vegetative state since being crushed in the Hillsborough disaster a shade less than four years previously. Here, too, the question had concerned the withdrawal of treatment from a patient deemed not to be benefitting from it. I shall return to the judgment from Bland in a while, because it played an important role in shaping subsequent Indian judicial opinion, but note in the meantime that there is a significant difference between the two cases. In Bland, the medical staff were willing to remove treatment, and were seeking clarity about the legality of so doing; in Shanbaug, the petition was brought not by the medical staff treating the patient but by a third party-and it is perhaps worth noting that Virani's claim to be Aruna Shanbaug's next friend was received with some scepticism by the Bench (6: para 14). That said, some of the fundamental questions in the two cases-about the existence and content of duties to provide life-sustaining treatment —are similar.

The Bench in Shanbaug also spent a great deal of time considering euthanasia. This is no small matter. That such considerations were deemed relevant at all indicates that the Court was inclined to treat a question of when it might be reasonable not to provide life-sustaining treatment as, more or less, a question of when euthanasia might be permissible. This would be in keeping with Definition 3\#. After all, while it was proposed that Ms Shanbaug's doctors remove treatment, it does not follow from that that anyone intended her death: the petition did not mention taking other means to kill her in the event that she somehow survived the withholding of nutrition. There would be no reason to think about euthanasia at all were Definition 3 the moral and jurisprudential lodestone. And we do indeed find statements in Katju J's speech that cohere with Definition 3\# and that lend weight to the supposition that the bench was inclined to accept it. Thus:

Passive euthanasia entails withholding of medical treatment for continuance of life, e.g. withholding of antibiotics where without giving it a patient is likely to die, or removing the heart lung machine, from a patient in coma. (6: para 38)

and:

The difference between 'active' and 'passive' euthanasia is that in active euthanasia, something is done to end the patient's life while in passive euthanasia, something is not done that would have preserved the patient's life.

An important idea behind this distinction is that in 'passive euthanasia' the doctors are not actively killing anyone; they are simply not saving him. (6: paras 44-45)

While he admitted that not everyone is persuaded by the distinction, he said that he was (6: para 49).

However, matters are complicated by statements that Katju J made elsewhere in his speech. At paragraph 51, for example, he appeared to cleave to something much more like Definition 3, saying that "[p]assive euthanasia is usually defined as withdrawing medical treatment with a deliberate intention of causing the patient's death" (6: para 51; emphasis mine); and in the statement later in the same paragraph that "[d] enying food to a person in coma or PVS may also amount to passive euthanasia", the word "may" is important: withholding life-sustaining interventions implicitly need not be seen as passive euthanasia. This "may" would be out of place if one were committed to Definition 3\#. Depending on which part of the speech one reads, then, Katju J's understanding of the term "passive euthanasia" appears to vary-sometimes more like Definition 3, and sometimes more like Definition 3\#.

But, as I noted a moment ago, Definition 3 and Definition $3 \#$ are, at the very least, in tension with each other; and this means that we have to choose to accept one or the other. Correspondingly, moving between them without even acknowledging their fundamental difference would seem to 
cast some doubt on the reliability of any reasoning concerning the nature of passive euthanasia. And, of course, since reasoning about the lawfulness of passive euthanasia depends on clarity concerning its nature, one might well expect there to be a knock-on effect there.

When considering the lawfulness of passive euthanasia, Katju J noted the view held by some commentators that:

while we can debate whether active euthanasia should be legal, there can be no debate about passive euthanasia: You cannot prosecute someone for failing to save a life. Even if you think it would be good for people to do $X$, you cannot make it illegal for people to not do $X$, or everyone in the country who did not do $X$ today would have to be arrested. (6: para 46)

A simple-perhaps simplistic-reading of this would take it at face value, and treat it as a claim that, since there are many instances in which it would be absurd to prosecute someone for not saving a life, and since passive euthanasia is not saving a life, it would be absurd to prosecute someone for passive euthanasia. But such a reading would be fallacious. After all, even if some instances of not saving a life ought not to be prosecuted, it doesn't follow that no instance should. The fact that there are some-perhaps many-instances in which Aisha is not and ought not to be prosecuted for not saving Arjun's life will not tell us about every possible Aisha and every possible Arjun. A lot depends on the context in which we find them, Aisha's capabilities, and so on. More importantly, a lot seems to ride on whether we think that Aisha has an allthings- considered duty at least to try to save Arjun's life. And so Katju J rightly held back from endorsing the view he had articulated, and clarified matters a little later:

In fact we have many laws that penalize people for what they did not do. A person cannot simply decide not to pay his income taxes, or to bother to send his/ her children to school (where the law requires sending them), or not to obey a policeman's order to put down one's [sic] gun. (6:para 48)

The subtext here is that it may be proper to prosecute someone for not having done something, provided that it is the sort of thing that one would have a legal duty to do in the normal run of things. And so the question would still be one of whether the medical staff looking after a particular patient had a legal duty to preserve that patient's life, given that not everybody does have that duty, given what is medically possible, and so on. However, if it is decided that it would be lawful for medical staff not to administer lifesustaining treatment to at least some of their patients, and if, per Definition 3\#, not sustaining that life is passive euthanasia, it would follow that passive euthanasia would be (or, at least, could be) lawful in India.

It is worth repeating that much here depends on accepting Definition 3\#; if one thinks that (in line with Definition 3) there is a class of withholding treatment that is not passive euthanasia, then the lawfulness of passive euthanasia cannot be deduced from the lawfulness of a given instance of withholding treatment without further specifying that this is the kind of withholding that is properly classed as passive euthanasia.

But having satisfied itself that, irrespective of any intention, a medic who does not treat is engaged in providing passive euthanasia, the Court decided that passive euthanasia, qua withdrawing life-sustaining treatment from Ms Shanbaug, was potentially lawful, subject to the medical staff caring for her seeking and obtaining the permission from the Bombay High Court (6: para 126).

In articulating the Court's decision, Katju J opined that this was entirely in line with the legal position in other countries:

The general legal position all over the world seems to be that while active euthanasia is illegal unless there is legislation permitting it, passive euthanasia is legal even without legislation provided certain conditions and safeguards are maintained. (6: para 39)

Since relatively few jurisdictions have legislated to permit the intentional ending of patients'lives, this could only be true granted Definition 3\#. And there is a reasonable number of people who would go along with the supposition that it is not uncommon to find regimes in which passive euthanasia, so long as it is understood in accordance with Definition 3\#, is legal. For example, in his hugely influential The value of life, John Harris writes that "the law forbids active euthanasia, but passive euthanasia is outlawed only where there exists a positive duty to save life" (9: p 39; slightly modified for context)—which implies that passive euthanasia is legal except where it is expressly forbidden. Leanne Bell writes in her 2012 textbook Medical law and ethics that "passive euthanasia involves the withholding or withdrawing of treatment from the patient, i.e. an omission rather than an act, and, in certain circumstances, can be legal" (10: p 204). Similarly, Banovi et al assert confidently that "active direct euthanasia is a forbidden way of the deprivation of the patients' life, while its passive form is commonly accepted" (11: p 173). Likewise, with an emphasis on Germany, Trappe asserts that

[p]assive euthanasia is the omission or reduction of possibly life-prolonging treatment measures. Passive euthanasia requires the patient's consent and is legally and ethically permissible. (12:p 216)

For their part, Khader and Mrayyan argue for the legal permissibility of passive euthanasia in Jordan, based on their understanding of the term to cover "allowing a patient to die by withholding treatment" (13: pp 111-12) — that is, based on having accepted a version of Definition 3\#.

Nevertheless, the problem should be clear. As we have seen, Katju J's speech appears sometimes to cohere with Definition 3, and sometimes with Definition 3\#. Since the two are incompatible-intention to end life either is or isn't part of the concept of passive euthanasia, and can't be both-this must 
be seen as a potential weakness in the ruling.

\section{Passive euthanasia after Shanbaug}

In 2012, in the light of Shanbaug, the Law Commission of India published a review of the law on passive euthanasia, which proceeded on the understanding that passive euthanasia

involves withholding of medical treatment or withholding lifesupport system [s] for continuance of life [...]. The core point of distinction between active and passive euthanasia as noted by [the] Supreme Court is that in active euthanasia, something is done to end the patient's life while in passive euthanasia something is not done that would have preserved the patient's life. (14: para 1.2)

This is clearly reflective of Definition 3\#. If there had been weaknesses in the Shanbaug decision, statements like this would stand a decent chance of mitigating them: stipulating that, henceforward, a particular phrase or concept is to be interpreted thus and so is a perfectly workaday piece of positivistic law making. The Commission asserted further that "[t]he Supreme Court [made] it clear that passive euthanasia is permissible in our country as in other countries" (14, para 6.1). And even if one does not agree that passive euthanasia is as obviously permissible in other countries as it is made out to be here, that does not really matter. Sovereign legislatures are free to define terms as they see fit.

Shanbaug's influence was felt again in 2018, when the Indian Supreme Court ruled in the case of Common Cause (15), which considered whether there was a Constitutionallyguaranteed right to die with dignity, and in which the Bench spent a great deal of time considering the jurisprudence of passive euthanasia and end-of-life treatment both in India and around the world. Whatever progress had been made by the Law Commission in shoring up a clear definition of "passive euthanasia", however, seems not to have been quite enough: when the judgment was published in March 2019, there was, once again, inconsistency concerning the definition of terms - if anything, more flagrant than there had been in Shanbaug. Misra CJl, referring to Shanbaug, repeated the claim in his speech that "passive euthanasia is usually defined as withdrawing medical treatment with a deliberate intention of causing the patient's death" (15: per Misra CJ, para 27; emphasis mine)-which reflects Definition 3. This understanding is apparently confirmed at the beginning of paragraph 44:

Euthanasia is basically an intentional premature termination of another person's life either by direct intervention (active euthanasia) or by withholding life-prolonging measures and resources (passive euthanasia) either at the express or implied request of that person (voluntary euthanasia) or in the absence of such approval/consent (non-voluntary euthanasia). (15: per Misra CJl, para 44; emphasis mine)

However, at the end of that same paragraph, he stated that [t]he main idea behind the distinction [between active and passive euthanasia], as observed by the Bench [in Shanbaug], is that in passive euthanasia, the doctors are not actively killing the patient, they are merely not saving him and only accelerating the conclusion of the process of natural death which has already commenced. (ibid)

This represents a slide to Definition 3\#: an intent to end life is apparently no longer important. It is a slide that Misra CJ appears not to have noticed or tried to halt, but confirmed later in his speech:

In active euthanasia, a specific overt act is done to end the patient's life whereas in passive euthanasia, something is not done which is necessary for preserving a patient's life. (15: per Misra CJI, para 195(vi))

Neither was it a slide resisted by the other judges hearing the case. Indeed, at paragraph 98 of his opinion, Chandrachud J said explicitly that "[i]n a case involving passive euthanasia, [t] here is neither an animus nor an intent to cause death." (15: per Chandrachud J, para 98)

However, the slide from Definition 3 to Definition 3\# was important, since it informed the Bench's pronouncements about the legality of passive euthanasia, which largely echoed those made in Shanbaug. Misra CJl asserted repeatedly that passive euthanasia is legal in several countries-for example, he said that

[i]t is perhaps due to the distinction evolved between [active and passive]euthanasia, which has gained moral and legal sanctity all over, that most of the countries today have legalized passive euthanasia either by way of legislations or through judicial interpretation but there remains uncertainty whether active euthanasia should be granted legal status. (15: para 49)

Versions of this statement can be found throughout the opinion-and, again, it attracted no demurral from other judges (vide 15: per Bhushan J, para 80). Once again, the statement can only be true if we accept Definition 3\#. But it is worth noting that, in making this statement, Misra CJI drew significant support for this claim from Lord Goff 's speech in the English Bland case. He advanced the claim that

Lord Goff observed that passive euthanasia includes cases in which a doctor decides not to provide, or to continue to provide, for his patient, treatment or care which could prolong his life and active euthanasia involves actively ending a patient's life, for example, by administering a lethal drug. (15: per Misra CJl, para 48)

The problem with this is that Misra $\mathrm{CJ}$ is flat-out wrong.

In Bland, Lord Goff did point out that

the law draws a crucial distinction between cases in which a doctor decides not to provide, or to continue to provide for his patient treatment or care which could or might prolong his life 
and those in which he decides, for example by administering a lethal drug, actively to bring his patient's life to an end. (8: p867)

While the former may be lawful, he continued, the latter would not be. In fairness to Misra CJI, if we adhere to Definition 3\#, then this would allow us to deduce that passive euthanasia would be legal, in line with its being nothing but the nonprovision of life-sustaining treatment when such nonprovision is lawful. (Negligent non-provision would clearly be unlawful.) However, there is no reason to suppose that Lord Goff had anything like Definition 3\# in mind. Contrary to Misra CJI's assertion, Lord Goff made no direct reference to passive euthanasia at all. What he did suggest was that

it is not lawful for a doctor to administer a drug to his patient to bring about his death, even though that course is prompted by a humanitarian desire to end his suffering, however great that suffering may be. So to act is to cross the Rubicon which runs between on the one hand the care of the living patient and on the other hand euthanasia-actively causing his death to avoid or to end his suffering. Euthanasia is not lawful at common law. (8: $p$ 867, slightly modified)

The final clause of the penultimate sentence here is, I think, important: Lord Goff understands euthanasia to be nothing but actively causing death with a motivation to end suffering. He does not make any statement about the legality of passive euthanasia because, simply put, it never appears to occur to him that there might be something to say. ( This understanding was repeated in 2017 by Sir Ernest Ryder in his speech in Conway (16: para 8). He does talk a little later about a doctor who "is simply allowing his patient to die of his pre-existing condition", but he does not refer to that as killing-and therefore not as euthanasia. This doctor is, in fact, contrasted to an interloper who switches off a lifesupport machine and who does, nefariously in this case, intend the patient's death. (8:p 868) In other words, though Lord Goff gave himself the opportunity to say that withdrawing treatment would be passive euthanasia, he did not actually say it. On this basis, we may infer that he did not understand all withdrawal or withholding to be such. Withholding treatment may be lawful when the intention is not to end life; euthanasia of any form is not lawful; therefore the lawful withholding of treatment cannot be euthanasia.

This means that the Bench in Common Cause appears to have been inaccurate in its use of Bland. Indeed, the term "passive euthanasia" is used only once in the entire Bland judgment, and by Lord Mustill, not Lord Goff ; in this context, the term is once again understood according to Definition 3, and-though this part of the speech is a little unclear- there is no clear claim made that it would be lawful either way (8: $p$ 891). In other words, in looking for an authority to back up their decisions, it would seem that the Indian Bench had seriously misunderstood a case that was central to its own reasoning, and upon which it relied heavily. This ought to trouble us, because it suggests that there may be cracks in the legal edifice.

\section{Why this matters}

To recap: Shanbaug concerned the withdrawal of lifesustaining treatment; in the course of deciding that it would be permissible in principle to withdraw life-sustaining treatment in this case, Katju J saw fit to declare that such withdrawals amount to passive euthanasia and that, therefore, passive euthanasia was lawful in India. Yet this declaration came in the context of a speech that drew on two competing definitions of passive euthanasia, and so it is not clear how his words should be interpreted. Nevertheless, his opinion was incorporated into the review of the law published in 2012 by the Law Commission of India, and restated in 2018 in the Common Cause ruling, which-again-obscured the question of whether passive euthanasia required the intent to end life. As such, there is a potential difficulty in working out what the judicial findings are supposed to mean, given that they allowed for ambiguity in respect of whether the intention to end the life of the patient was a necessary part of an action's counting as passive euthanasia.

There is a number of reasons why this might be a concern.

In the first place, there is a general point to be made that any set of laws in which the definition of a central term is unclear is likely to be vulnerable to all manner of objections as a matter of principle. But there are reasons why we may be concerned in practice.

Neither Shanbaug nor Common Cause sought to establish that medical staff may set out to end life. The Bill proposed at the end of the Law Commission's report did not consider that possibility either: it was concerned with a patient's right to refuse treatment. We may assume, then, that the judges who ruled in those cases, and the members of the Law Commission, intended their comments and proposals to refer solely to those patients from whom it was proposed to withhold lifesustaining treatment. And yet by defining this as "passive euthanasia", and failing to differentiate between the intentional and merely foreseen ending of a life, the way was left open for their recommendations to be taken as permitting least some instances of one person's intentionally ending another's life. That is to say: because insufficient care was taken to distinguish withholding treatment even though the patient would die from withholding treatment so that the patient would die, it is possible to draw the inference that at least some instances of intentional killing in the medical context are permissible in India. This takes the legal position far beyond what Shanbaug or Common Cause (or, for that matter, Bland) were about, and it is not at all clear that this outcome was intended by anyone. Whatever one's position on the moral permissibility of euthanasia, and on whether the law should allow mercy-killing, the idea that end-of-life care might be governed by policies that display a lack of attention in defining key terms is deeply worrying.

The Shanbaug and Common Cause cases must surely provide an object lesson in how not to talk about euthanasia. 


\section{Competing interests and funding: None declared}

\section{Statement of similar work}

Section 2 gives a brief rehearsal of the definitions of passive euthanasia that is developed at more length in my essay 'What passive euthanasia is', published in BMC Medical Ethics (1).

Acknowledgements: I am very grateful to Margot Brazier, Swati Gola, Soren Holm, and Alex Mullock for their comments on an earlier draft of this paper. The paper has also benefitted from helpful suggestions from the reviewers and editorial staff of this journal. Any improvements arising from their comments are due to them; any lapses are due to me.

\section{References}

1. Brassington I. What passive euthanasia is. BMC Med Ethics. 2020 May 14 [accessed $2020 \mathrm{Jul}$ 7]; 21(41). Available from: https://bmcmedethics. biomedcentral.com/articles/10.1186/s12910-020-00481-7

2. Draper D. Euthanasia. In: Chadwick R, editor. Encyclopedia of Applied Ethics, vol. 2. San Diego: Academic Press; 1998.

3. Shukla R. Passive euthanasia in India: A critique. Indian J Med Ethics. 2016 Jan-Mar; 1(1): 35-8.

4. Varelius J. Mental illness, natural death, and non-voluntary passive euthanasia. Ethic Theory Moral Prac. 2016; 19(3): 635-48.

5. British Broadcasting Corporation. Date unknown [cited $2020 \mathrm{Jul}$ 7]. Available from http://www.bbc.co.uk/ethics/euthanasia/overview/ activepassive_1.shtml

6. Supreme Court of India. Aruna Ramchandra Shanbaug v. Union of India and Others, [2011] INSC 222. Available from http://www.liiofindia.org/ in/cases/cen/INSC/2011/222.html [accessed 2020 Jul 7]

7. Supreme Court of India. Smt Gian Kaur v. The State of Punjab, 1996 INSC 434. Available from: http://www.liiofindia.org/in/cases/cen/ INSC/ 1996/434.html [accessed 2020 Jul 7]

8. House of Lords. Airedale NHS Trust v Bland, 19931 All ER 821

9. Harris J. The value of life. London: Routledge; 1985.

10. Bell L. Medical law and ethics. Harlow: Pearson; 2012.

11. Banovi B, Turanjanin V, Miloradovi A. An ethical review of euthanasia and physician-assisted suicide. Iran J Public Health. 2017 Feb; 46(2): 173 9.

12. Trappe H. Ethik in intensivmedizin und sterbehilfe [Ethics in intensive care and euthanasia]. Med Klin Intensivmed Notfmed. 2017; 112:21421.

13. Khader A, Mrayyan M. Euthanasia for children with cancer: A policy brief. IOSR Journal of Nursing and Health Science. 2017; 6(1):111-12.

14. Law Commission of India. Passive euthanasia - A relook (Report No. 241) New Delhi: Government of India; 2012 Aug [cited 2020 Jul 7] Available from: https://indiankanoon.org/docfragment/133438875/? formlnput=I aw\%20commission

15. Supreme Court of India. Common Cause (A Regd. Society) v Union of India, 2018 INSC 204[cited 2020 Jul 7]. Available from http:// www.liiofindia. org/in/cases/cen/INSC/2018/204.html [accessed 2020 Jul 7]

16. Court of Appeal (Civil Division). Conway v Secretary of State for Justice [2018] EWCA Civ 16 [cited 2020 Jul 7]. Available from https://www. judiciary.uk/judgments/noel-douglas-conway-v-secretary-of-state-forjustice-permission-to-appeal/

\section{Be a part of IJME}

IJME invites readers to submit research studies, comments, case studies, reports, reviews, letters, as also poems, short stories, original paintings and photographs of print quality ( both in colour and B/W ) to be considered for publication.

All submitted matter is subject to peer review.

Contributors are neither paid nor charged any fee for published matter. 